\title{
AKTIVITAS PENYELESAIAN KREDIT PADA PT. BANK NAGARI CABANG SOLOK SELATAN
}

\author{
Novil Dwi Wandra, Mariani St.B Tanjung \\ Akademi Keuangan dan Perbankan Padang \\ mstbtanjung@gmail.com
}

\begin{abstract}
ABSTRAK
Tujuan penelitian ini yaitu untuk mengetahui bagaimana prosedur penyelesaian kredit bermasalahan yang dilakukan oleh Bank Nagari Cabang Solok Selatan. Metode analisis data menggunakan analisis data kualitatif sebagai metode penelitian yang menjelaskan secara deskriptif mengenai uraian data secara sistematis dari faktafakta yang didapat kemudian dihubungkan dengan aktivitas penyelesaian kredit pada Bank Nagari Cabang Solok Selatan. Hasil penelitian 1) Memberikan keringanan pembayaran bunga. 2) Keringanan tunggakan pokok. 3) Mendesak debitur untuk melakukan sendiri penjualan agunan.
\end{abstract}

Kata Kunci: Kredit, Bank

\section{PENDAHULUAN}

Perbankan merupakan sektor terpenting dalam laju perekonomian suatu negara. Semua permasalahan yang dihadapi oleh dunia perbankan, sangat mempengaruhi semua tatanan yang berhubungan dengan laju pertumbuhan ekonomi. Setiap penyaluran kredit oleh kreditur tentu mengandungresiko, karena adanya keterbatasan kemampuan manusia dalam memprediksi masa yang akan datang, untuk itu bank harus merencanakan sedemikian rupa dan berusaha untuk menekan resiko munculnya kredit bermasalah.

Kredit bermasalah merupakan fenomena yang disebabkan berbagai faktor yang berkaitan satu sama lainnya, untuk itu harus segera mungkin mendapatkan penyelesaian karena dapat menyebabkan terganggunya kondisi bank. Berdasarkan uraian diatas maka penulis tertarik memilih judul Aktivitas Penyelesaian Kredit Pada PT. Bank Nagari Cabang Solok Selatan. Berdasarkan latar belakang masalah yang telah diuraikan di atas, maka permasalahan yang di angkat dalam proposal ini adalah Bagaimana aktivitas penyelesaian kredit pada PT. Bank Nagari Cabang Solok Selatan?

Bank Pembangunan Daerah Sumatera Barat secara resmi berdiri pada tanggal 12 Maret 1962 dengan nama "PT. BANK PEMBANGUNAN DAERAH SUMATERA BARAT" yang disahkan melalui akta notaris Hasan Qolbi di Padang. Pendirian tersebut dipelopori oleh Pemerintah Daerah beserta tokoh masyarakat dan tokoh pengusaha swasta di Sumatera 
Barat atas dasar pemikiran perlunya suatu lembaga keuangan yang berbentuk Bank, yang secara khusus membantu pemerintah dalam melaksanakan pembangunan di daerah. Disahkan melalui Surat Keputusan Wakil Menteri Pertama Bidang Keuangan Republik Indonesia No. BUM/944/II tentang izin usaha PT. Bank Pembangunan Daerah Sumatera Barat dengan kedudukan di Padang. Cabang Solok Selatan berdiri karena adanya pemekaran wilayah di Kabupaten Solok 7 Januari 2014, maka dari itu kantor cabang pembantu yang ada di Solok Selatan dirubah jadi kantor cabang utama yang berpusat di Padang Aro, kantor cabang tersebut diresmikan langsung oleh Gubernur Sumatera Barat dan direktur bank nagari.

Produk Kredit Bank Nagari :

1. Kredit Konsumtif:

a. Kredit Cicilan Uang (KCU) Kredit cicilan uang (KCU) yang selanjutnya disebut dengan KCU-Umum, adalah pinjaman yang diberikan Bank kepada Pegawai Negeri Sipil (PNS) Non Otonom atau PNS Vertikal, TNI/POLRI, pegawai melalu PT. Bank Nagari Sumatera Barat maupun yang gajinya tidak dibayarkan melaluiPT. Bank Nagari Sumatera Barat.

b. Kredit Pensiun:

Kredit cicilan uang Pensiunan Pegawai adalah pinjaman yang diberikan Bank kepada pensiunan Pegawai Negeri Sipil (PNS), PensiunanTNI/POLRI, Pensiunan Pegawai BUMN/BUMD yang uang pensiunnya diabayar melalaui PT. Bank Pembangunan Daerah Sumatera Barat.

2. Kredit Komersil

Kredit Modal Kerja Multi Guna (KMK-MG)

Kredit Modal Kerja Multi Guna adalah kredit diberikan untuk modal kerja debitur dan calon debitur baik usaha perorangan yang mempunyai perizinan formal atau tidak mempunyai perizinan formal maupun berbentuk badan usaha/badan hukum dan lainya untuk berbagai sektor ekonomi

\section{LANDASAN TEORI}

\section{Pengertian Bank Nagari}

Menurut Kasmir Pengertian bank pada awal dikenalnya adalah meja tempat menukar uang

Undang-Undang Perbankan Nomor 10 Tahun 1998 pasal 1 butir ( 2), tentang perubahan atas Undang-Undang Perbankan Nomor 7 Tahun 1992 menyebutkan bahwa bank adalah badan usaha yang menghimpun dana dari masyarakat dalam bentuk simpanan dan menyalurkannya kepada masyarakat dalam bentuk kredit dan/ atau bentuk-bentuk lainnya dalam rangka meningkatkan taraf hidup rakyat banyak.

\section{Pengertian Kredit}

Pengertian kredit menurut Hasibuan adalah :

a. Kredit berasal dari bahasa Italia, credere yang artinya kepercayaan, yaitu kepercayaan dari kreditur bahwa debiturnya akan 
mengembalikan pinjamannya beserta bunganya sesuai dengan perjanjian kedua belah pihak.

b. Pengertian kredit menurut Kasmir, kredit berasal dari bahasa latin yang disebut credere yang artinya percaya, maksudnya sipemberi kredit percaya kepada sipenerima kredit bahwa kredit yang disalurkannya pasti akan dikembalikan sesuai perjanjian, sedangkan bagi sipenerima kredit berarti menerima kepercayaan, sehingga mempunyai kewajiban untuk membayar kembali sesuai dengan jangka waktunya.

3. Jenis-Jenis Kredit

Menurut Kasmir, jenis-jenis kredit dibagi dalam 7 kelompok yaitu

\section{a. Dilihat dari segi kegunaan}

1) Kredit investasi

Biasanya digunakan untuk keperluan usaha atau membangun proyek, pabrik baru atau untuk keperluan rehabilitasi.

2) Kredit modal kerja

Digunakan untuk keperluan meningkatkan produksi dalam operasionalnya. Dilihat dari segi tujuan kredit

3) Kredit produktif

Kredit yang digunakan untuk meningkatkan usaha produksi atau investasi. Kredit ini diberikan untuk menghasilkan barang atau jasa.

4) Kredit konsumtif

Kredit yang digunakan untuk konsumsi secara pribadi

5) Kredit perdagangan

Kredit yang digunakan untuk perdagangan, biasanya digunakan untuk membeli barang dagangan yang pembayarannya diharapkan dari hasil penjualan barang dagangan tersebut.

\section{b. Dilihat dari segi jangka waktu}

1) Kredit jangka pendek Merupakan kredit yang memiliki jangka waktunya paling lama 1 tahun dan biasanya digunakan untuk modal kerja.

2) Kredit jangka menengah Jangka waktu kreditnya berkisar antara 1 tahun sampai dengan 3 tahun, biasanya untuk investasi.

3) Kredit jangka panjang Merupakan kredit yang masa pengembaliannya paling panjang. Kredit jangka panjang waktu pengembaliannya diatas 3 tahun atau 5 tahun. Biasanya kredit ini untuk investasi jangka panjang seperti perkebunan karet, kelapa sawit atau manufaktur dan untuk kredit konsumtif seperti perumahan.

\section{c. Dilihat dari segi jaminan}

1) Kredit dengan jaminan

Kredit yang diberikan dengan suatu jaminan, jaminan tersebut dapat berbentuk barang yang berwujud atau tidak berwujud atau jaminan orang. 
2) Kredit tanpa jaminan

Merupakan kredit yang diberikan tanpa jaminan barang atau orang tertentu..

3) Dilihat dari sektor

$\checkmark$ Kredit pertanian, merupakan kredit yang dibiayai untuk sektor perkebunan atau pertanian rakyat. Sektor usaha pertanian dapat berupa jangka pendek atau jangka panjang.

$\checkmark$ Kredit perternakan, dalam hal ini untuk jangka pendek misalnya perternakan ayam, dan jangka panjang kambing atau sapi.

$\checkmark$ Kredit industri, yaitu kredit untuk membiayai industri kecil, menengah, atau besar.

$\checkmark$ Kredit pertambangan, jenis usaha tambang yang dibiayai biasanya dalam jangka panjang seperti tambang emas, minyak atau timah.

$\checkmark$ Kredit pendidikan, merupakan kredit yang diberikan untuk membangun sarana dan prasarana pendidikan atau dapat pula berupa kredit untuk mahasiswa.

$\checkmark$ Kredit profesi, diberikan kepada profesional sepeti dosen, dokter atau pengacara.

$\checkmark$ Kredit perumahan, yaitu kredit untuk membiayai pembangunan atau pembelian rumah.

\section{B. Analisis Kredit}

Menurut Rivai tujuan analisis kredit adalah untuk memperoleh keyakinan apakah nasabah mempunyai kemauan memenuhi kewajibannya secara tertib kepada bank

Hal yang perlu diperhatikan dalam menganalisis kredit yaitu nasabah harus memenuhi prinsip 6C yaitu sebagai berikut :

\section{Character}

Adalah keadaan watak/ sifat dari nasabah baik dalam kehidupan pribadi maupun dalam lingkungan usaha.

2. Capital

Adalah jumlah dana/ modal sendiri yang dimiliki oleh calon nasabah.

\section{Capacity}

Adalah kemampuan yang dimilki calon nasabah dalam menjalankan usahanya guna memperoleh laba yang diharapkan.

\section{Collateral}

Adalah barang-barang yang diserahkan nasabah sebagai anggunan terhadap kredit yang diterimanya. Penilaian terhadap collateral ini dapat ditinjau dari dua segi sebagai berikut :

a) Segi ekonomis, yaitu nilai ekonomis dari barang-barang yang akan diagunkan.

b) Segi yuridis, yaitu apakah jaminan tersebut memenuhi syaratsyarat yuridis untuk dipakai sebagai jaminan. 


\section{Condition of Economy}

Adalah situasi dan kondisi politik, sosial, ekonomi, budaya yang mempengaruhi keadaan perekonomian pada suatu saat yang kemungkinannya mempengaruhi kelancaran perusahaan calon debitur.

6. Contraint

Adalah batasan dan hambatan yang tidak memungkinkan suatu bisnis untuk dilaksanakan pada tempat tertentu.

\section{PEMBAHASAN}

\section{A. Pengertian Kredit}

Pengertian kredit menurut Hasibuan adalah :

Kredit berasalah dari bahasa Italia, credere yang artinya kepercayaan, yaitu kepercayaan dari kreditur bahwa debiturnya akan mengembalikan pinjamannya beserta bunganya sesuai dengan perjanjian kedua belah pihak.

Penyediaan uang atau tagihan yang dipersamakan dengan itu berdasarkan persetujuan atau kesepakatan pinjam-meminjam antara bank dengan pihak lain yang mewajibkan pihak peminjam untuk melunasi hutangnya setelah jangka waktu tertentu dengan jumlah bunga imbalan atau pembagian hasil keuntungan.

Semua jenis pinjaman yang harus dibayar kembali bersama bunganya oleh peminjam sesuai dengan perjanjian yang telah disepakati.

Hak untuk menerima pembayaran atau kewajiban untuk melakukan pembayaran tepat pada waktu yang diminta atau pada waktu yang akan datang.

Pengertian kredit menurut Kasmir, kredit berasal dari bahasa latin yang disebut credere yang artinya percaya, maksudnya sipemberi kredit percaya kepada sipenerima kredit bahwa kredit yang disalurkannya pasti akan dikembalikan sesuai perjanjian, sedangkan bagi sipenerima kredit berarti menerima kepercayaan, sehingga mempunyai kewajiban untuk membayar kembali sesuai dengan jangka waktunya.

\section{B. Jenis-Jenis Kredit}

Menurut Kasmir, jenis-jenis kredit dibagi dalam 7 kelompok yaitu :

1. Dilihat dari segi kegunaan

a. Kredit investasi

Biasanya digunakan untuk keperluan usaha atau membangun proyek, pabrik baru atau untuk keperluan rehabilitasi. Contoh kredit investasi misalnya untuk membangun pabrik atau membeli mesin-mesin.

b. Kredit modal kerja

Digunakan untuk keperluan meningkatkan produksi dalam operasionalnya. Contoh kredit modal kerja diberikan untuk membeli bahan baku, membayar gaji pegawai atau biaya-biaya lainnya yang berkaitan dengan proses produksi perusahaan. 
2. Dilihat dari segi tujuan kredit

a. Kredit produktif

Kredit yang digunakan untuk meningkatkan usaha produksi atau investasi. Kredit ini diberikan untuk menghasilkan barang atau jasa. Contoh kredit untuk membangun pabrik yang nantinya akan menghasilkan barang, kredit pertanian atau kredit pertambangan menghasilkan bahan tambang atau kredit industri lainnya.

b. Kredit konsumtif

Kredit yang digunakan untuk konsumsi secara pribadi. Dalam kredit ini tidak ada pertambahan barang atau jasa yang dihasilkan, karena memang untuk digunakan atau dipakai oleh seseorang atau badan usaha. Sebagai contoh kredit untuk perumahan, kredit untuk mobil pribadi, kredit perabotan rumah tangga dan kredit konsumtif lainnya.

c. Kredit perdagangan

Kredit yang digunakan untuk perdagangan, biasanya digunakan untuk membeli barang dagangan yang pembayarannya diharapkan dari hasil penjualan barang dagangan tersebut. Kredit ini sering diberikan kepada para pedagang.

3. Dilihat dari segi jangka waktu

a. Kredit jangka pendek

Merupakan kredit yang memiliki jangka waktunya paling lama 1 tahun dan biasanya digunakan untuk modal kerja. Contohnya untuk pertanian, menanam padi.

b. Kredit jangka menengah

Jangka waktu kreditnya berkisar antara 1 tahun sampai dengan 3 tahun, biasanya untuk investasi. Sebagai contoh kredit untuk pertanian seperti jeruk, atau perternakan kambing.

c. Kredit jangka panjang

Merupakan kredit yang masa pengembaliannya paling panjang. Kredit jangka panjang waktu pengembaliannya diatas 3 tahun atau 5 tahun. Biasanya kredit ini untuk investasi jangka panjang seperti perkebunan karet, kelapa sawit atau manufaktur dan untuk kredit konsumtif seperti perumahan.

4. Dilihat dari segi jaminan

a. Kredit dengan jaminan

Kredit yang diberikan dengan suatu jaminan, jaminan tersebut dapat berbentuk barang yang berwujud atau tidak berwujud atau jaminan orang. Artinya setiap kredit yang dikeluarkan akan dilindungi jaminan nya oleh calon debitur.

b. Kredit tanpa jaminan

Merupakan kredit yang diberikan tanpa jaminan barang atau orang tertentu. Kredit jenis ini diberikan dengan melihat prospek usaha dan karakter serta loyalitas atau nama baik sicalon debitur selama ini. 


\section{Dilihat dari sektor}

a. Kredit pertanian, merupakan kredit yang dibiayai untuk sektor perkebunan atau pertanian rakyat. Sektor usaha pertanian dapat berupa jangka pendek atau jangka panjang.

b. Kredit perternakan, dalam hal ini untuk jangka pendek misalnya perternakan ayam, dan jangka panjang kambing atau sapi.

c. Kredit industri, yaitu kredit untuk membiayai industri kecil, menengah, atau besar.

d. Kredit pertambangan, jenis usaha tambang yang dibiayai biasanya dalam jangka panjang seperti tambang emas, minyak atau timah.

e. Kredit pendidikan, merupakan kredit yang diberikan untuk membangun sarana dan prasarana pendidikan atau dapat pula berupa kredit untuk mahasiswa.

f. Kredit profesi, diberikan kepada profesional sepeti dosen, dokter atau pengacara.

g. Kredit perumahan, yaitu kredit untuk membiayai pembangunan atau pembelian rumah.

\section{Proses Dalam Pemberian Kredit}

\section{Kriteria calon debitur}

a. Warga Negara Indonesia yang cakap hukum (berusia minimal 21 tahun atau telah menikah dan berakal sehat).

b. Mempunyai usaha yang jelas dan dapat diyakini bank.

c. Tidak tercatat dalam daftar hitam dan debitur macet yang dikeluarkan oleh Bank Indonesia.

2. Persyaratan permohonan kredit

a. Foto copy kartu identitas diri ( KTP / SIM /Paspor) yang berlaku.

b. Pas photo ukuran $3 \times 4$ sebanyak 3 lembar.

c. Mempunyai perizinan sesuai dengan ketentuan yang berlaku (SIUP, TDP, SITU).

d. Mempunyai Nomor Pokok Wajib Pajak ( NPWP) sesuai dengan ketentuan Bank Indonesia dan menyerahkan foto copynya.

e. Untuk calon debitur yang berbentuk badan usaha, mempunyai anggaran dasar perusahaan berikutnya serta mempunyai laporan keuangan.

3. Identifikasi permohonan kredit

a. Pemeriksaan permohonan kredit diidentifikasi melakui pemeriksaan keabsahan permohonan dengan kelengkapan.

b. Identifikasi permohonan dilaksanakan dalam rangka pengumpulan data dan informasi yang diperlukan untuk analisis kredit Pemeriksaan dan penelitian

\section{Strategi Penyelesaian Kredit}

Memberikan surat tunggakan dan peringatan kepada debitur.

Yaitu surat pemberitahuan kepada debitur bahwa debitur mulai tidak memenuhi kewajiban kepada pihak bank 
1. Memberikan keringanan pembayaran bunga.

Yaitu Pemberian keringanan pembayaran bunga untuk penyelesaian kredit dengan kolektibilitas diragukan dan macet dengan cara pembayaran secara lunas ataupun secara angsuran.

2. Keringanan tunggakan pokok

Adalah upaya penyelesaian kredit dengan pemberian keringanan hutang pokok kepada debitur yang mau melunasi hutangnya sekaligus.

3. Mendesak debitur untuk melakukan sendiri penjualan agunan.

\section{PENUTUP}

\section{Kesimpulan}

Berdasarkan uraian yang telah dikemukakan, maka dapat ditarik kesimpulan sebagai berikut :

1. Dalam pelaksanaan pengawasan kredit Bank Nagari Cabang Solok Selatan didasarkan pada penelitian langsung ke tempat lokasi usaha debitur serta atas laporan-laporan yang diberikan oleh nasabah.

2. Untuk keamanan dari kredit yang diberikan kepada nasabah, maka Bank Nagari Cabang Solok Selatan meminta adanya jaminan kredit kepada calon nasabah.

3. Penyehatan kredit bermasalah yang dilakukan oleh Bank Nagari cabang Solok Selatan dapat dilakukan dengan kombinasi yaitu dengan cara memberi surat tunggakan dan peringatan kepada debitur, memberikan keringanan pembayaran bunga dan tunggakan pokok, serta mendesak debitur untuk menjual agunan.

4. Penyebab utama dari kredit bermasalah bisa karena kesalahan dari pihak bank yang kurang tajam dalam menganalisis latar belakang calon nasabah, sehingga maksud dan tujuan serta sumber pembayaran kembali kredit yang diberikan tidak dapat diketahui secara jelas. Rendahnya tingkat pendidikan nasabah yang menerima kredit, serta kurang adanya komunikasi yang terbuka antara nasabah dengan bank juga dapat menyebabkan terjadinya kredit bermasalah.

\section{Saran}

Setelah memperhatikan masalah yang dihadapi oleh Bank Nagari Cabang Solok Selatan maka penulis memberikan saran-saran sebagai berikut:

1. Karyawan bank hendaknya dapat memberikan pelayanan semaksimal mungkin terhadap nasabah dalam meningkatkan promosi untuk menarik minat masyarakat melakukan hubungan dengan bank, baik berupa simpanan maupun kredit.

2. Untuk mengantisipasi terjadinya kredit bemasalah sebaiknya bank meningkatkan monitoring dan pengawasan terhadap kredit yang diberikan baik mengenai manajemen maupun keadaan usaha debitur. 


\section{DAFTAR PUSTAKA}

Alanshari, F., \& Marlius, D. (2018). Prosedur Pemberian Kredit KPR Pada PT. Bank Tabungan Negara (Persero) TBK Cabang Pembantu Bukittinggi. https://doi.org/10.31227/osf.io/rsfhc

Amelia, L., \& Marlius, D. (2018). Pengendalian Kredit Dalam Upaya Menciptakan Bank Yang Sehat Pada PT. Bank Pembangunan Daerah Sumatera Barat Cabang Utama Padang. https://doi.org/10.31227/osf.io/kpc64

Andriani, B., \& Susanto, R. (2019). Pengawasan Kredit PT. Bank Perkreditan Rakyat (BPR) Ophir Pasaman Barat. https://doi.org/10.31219/osf.io/aunvc

Baiya, \& Fernos, J. (2019). Analisis Faktor-Faktor Penyebab Kredit Macet Pada Bank Nagari Cabang Siteba. https://doi.org/10.31227/osf.io/4xuks

Darmawanto, \& Fernos, J. (2019). Prosedur Pemberian Kredit Pada Bank Nagari Cabang Sijunjung. https://doi.org/10.31227/osf.io/psqfy

Firmansyah, A., \& Fernos, J. (2019). Analisis Kredit Bermasalah Dilihat Dari Standar Non Performing Loan (NPL) Pada PT. Bank Perkreditan Rakyat (BPR) Prima Mulia Anugrah Cabang Padang. https://doi.org/10.31227/osf.io/gcj94

Hasibuan, Melayu, Dasar Dasar Perbankan, PT Bumi Aksara, Jakarta, 2004.

Ikbal, M., \& Marlius, D. (2017). Pengaruh Jumlah Taksiran Dan Uang Pinjaman Terhadap Laba Bersih Pada PT. Pegadaian (UPC) Gurun Laweh. https://doi.org/10.31227/osf.io/uch4a

Kasmir, Bank dan Lembaga Keuangan Lainnya, PT Raja Grafindo Persada, Jakarta, 2003.

Kasmir, Dasar-Dasar Perbankan, PT Raja Grafindo Persada, Jakarta, 2003.

Orlando, A., \& Susanto, R. (2019). Mekanisme Pencairan Kredit Usaha Rakyat Pada PT. Bank Rakyat Indonesia Unit Lubuk Buaya. https://doi.org/10.31219/osf.io/zuv2y

Pratama, D., \& Fernos, J. (2019). Prosedur Pelaksanaan Kredit Usaha Rakyat (KUR) Pada PT. Bank Nagari Cabang Padang. https://doi.org/10.31227/osf.io/ag68j 
Rivai Veithzal \& Anria Permata Veithzal, Credit Management Handbook, PT Raja Grafindo Persada,2006.

Shanjaya, A. R., \& Marlius, D. (2017). Peranan Laporan Keuangan Dalam Kebijaksanaan Pemberian Kredit Kepada Calon Nasabah Pada PT. BPR Batang Kapas. https://doi.org/10.31227/osf.io/uxmg6

Suhardjono, Mudrajad Kuncoro, Manajemen Perbankan, Fakultas Ekonomi UGM Yogyakarta, 2002.

Suharto, Pandu Drs, Sejarah Pendirian Bank Perkreditan Rakyat, LPPI, Jakarta, 1998.

Sutojo, Siswanto, Menangani Kredit Bermasalah, PT Damar Mulia Pustaka, Jakarta, 2008.

Suyatno, Thomas, Dasar Dasar Perkreditan, PT Gramedia Pustaka Utama, Jakarta, 2003.

Swastha, Basu, Pengantar Bisnis Modern, Liberty, Yogyakarta, 1999.

Undang-Undang Nomor 10 Tahun 1998 Tentang Perbankan, (2002), Jakarta, Sinar Grafika

Widayati, R. (2019). Penyelesaian Kredit Bermasalah Pada PT. Bank Perkreditan Rakyat (BPR) Nagari Kasang. https://doi.org/10.17605/OSF.IO/D4MF3

Widayati, R. (2019). Aktivitas Pemberian Kredit Komersil Pada Bank Nagari Cabang Sijunjung. https://doi.org/10.17605/OSF.IO/QTVZ9

Widayati, R. (2019). Pelaksanaan Kredit Pada Bank Perkreditan Rakyat LPN Pasar Baru Durian Sawahlunto. https://doi.org/10.17605/OSF.IO/5HPAB

Widayati, R. (2019). Upaya Penanganan Kredit Bermasalah Pada Bank Nagari Cabang Utama Padang. https://doi.org/10.17605/OSF.IO/YJ3KN

Widayati, R. (2019). Aktivitas Pemberian Kredit Usaha Pada PT. Bank Perkreditan Rakyat Batang Kapas. https://doi.org/10.17605/OSF.IO/EDPN4 